\title{
Dendrochronology of pedunculate oak (Quercus robur L.) in an old-growth pollarded woodland in northern Spain: tree-ring growth responses to climate
}

\author{
Vicente ROZAS ${ }^{\mathrm{a}, \mathrm{b} *}$ \\ a Departamento de Biología de Organismos y Sistemas, Universidad de Oviedo, Catedrático Rodrigo Uría, 33071 Oviedo, Spain \\ b Present address: Departamento de Ecología, Centro de Investigaciones Forestales y Ambientales de Lourizán, Carretera a Marín km 4 , \\ Apartado 127, 36080 Pontevedra, Spain
}

(Received 13 November 2003; accepted 15 September 2004)

\begin{abstract}
Both time-independent and time-dependent responses of radial growth in pedunculate oak (Quercus robur L.) to climate were investigated in an old-growth woodland in the Cantabrian lowlands, northern Spain. This was done by using correlation analysis, bootstrapped response functions and Kalman filter analysis. Responses to climatic factors were explored in three different oak age-classes: young $<120$ years, mature 170-225 years old, and old-growth trees 250-470 years. Time-independent climatic models showed age-specific responses Between 55.2 to $66.8 \%$ of ring-width discovered variance was explained by weather conditions in the period 1940-1998. Radial growth of young oaks was limited by the temperatures in June of the year the ring was formed, while mature and old-growth oaks showed a negative response to winter and summer temperatures, and a positive one to summer precipitation. Time-dependent models revealed that the effect of several climatic variables on tree growth was not constant through time. This variability could be explained by physiological changes related to tree ageing, while it was unrelated to changes in other environmental factors. Overall, these results suggest that any assumption of an ageindependent climate-growth relationship for oak in the studied locality is unreliable, and anticipate the probable responses of oaks growing in old-growth woodlands to global climatic changes.
\end{abstract}

climate / dendroecology / Kalman filter / response function / ring width

Résumé - Étude dendrologique du chêne pédonculé (Quercus robur L.) dans une forêt âgée, d'arbres traités en têtard, du nord de l'Espagne : influence du climat sur la largeur des cernes. Dans une forêt âgée, située à basse altitude dans la région Cantabrique, on a étudié les relations entre le climat et la largeur des cernes chez le chêne pédonculé (Quercus robur L.) ces relations pouvant être indépendantes ou dépendantes du temps. Pour ce faire, on a fait appel à la méthode de rééchantillonnage (bootstrapped response functions) et au filtre de Kalman. Les réponses aux facteurs climatiques ont été recherchées dans trois classes d'âge des chênes à savoir : les sujets jeunes (inf. à 120 ans), les sujets matures ( 170 à 225 ans), les très vieux arbres (250 à 470 ans). Les modèles climatiques indépendants du temps révèlent des réponses liées spécifiquement à l'âge. Entre 55,2 et 66,8 \% de la variance de l'épaisseur des cernes s'expliquent par les conditions climatiques au cours de la période 1940-1998. L'accroissement en diamètre des jeunes chênes est limité par les températures du mois de Juin de l'année de formation du cerne, tandis que chez les arbres matures ou très vieux, on enregistre une réponse négative avec les températures hivernales ou estivales, et une réponse positive avec l'augmentation des précipitations estivales. Les modèles dépendant du temps révèlent que l'effet des diverses variables climatiques sur la largeur des cernes n'est pas constant dans le temps. Cette variabilité pourrait s'expliquer par des changements d'ordre physiologiques liés au vieillissement des arbres ; elle ne peut être attribuée à des modifications d'autres facteurs de l'environnement. En conclusion, ces résultats permettent de douter de l'existence d'une relation climat/accroissement des cernes indépendantes de l'âge pour le chêne dans la zone étudiée. Ils contribuent aussi à entrevoir les conséquences probables de changements climatiques sur les vieux peuplements de chêne.

climat / dendroécologie / filtre de Kalman / fonction de réponse / largeur des cernes

\section{INTRODUCTION}

One objective of dendroclimatology focuses on the use of tree-ring widths to obtain information about long-term variation in climate. Tree-rings contain a wealth of information about the climatic conditions that affect the growth of trees and influence forest yield and sustainability [15]. In temperate deciduous forests the radial growth of trees has been reported to be less sensitive to climate than in arid woodlands and forests found near their latitudinal or altitudinal limit of distribution where there are more limiting conditions [15]. However, it has been discovered that climate is an important factor influencing

* Corresponding author: vrozas.cifal@siam-cma.org 


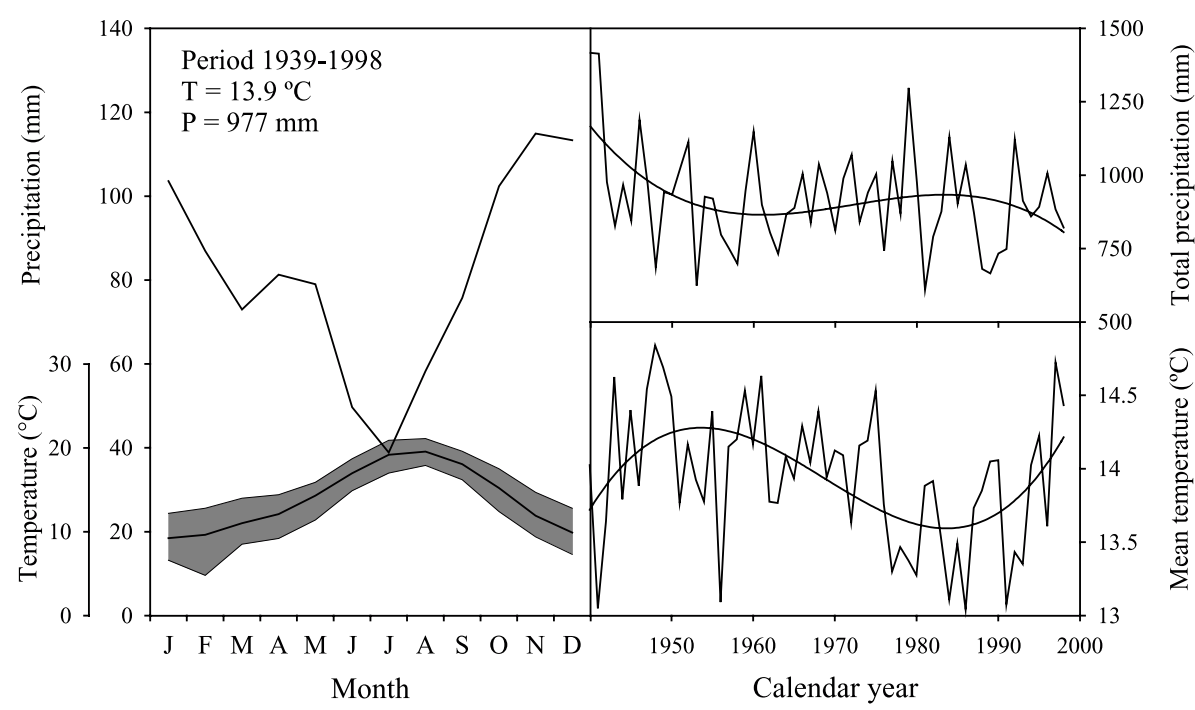

Figure 1. Climatic diagram of Gijón, Spain (43 $33^{\prime} \mathrm{N}, 05^{\circ} 39^{\prime} \mathrm{W}$ ) for 1939-1998. The range of variation of mean temperature (shaded area) is shown. T: mean annual temperature, P: mean annual precipitation. The variation of total annual precipitation and mean annual temperature, with their general trends, are shown.

the radial growth of tree species in temperate latitudes, in sites not traditionally considered to be largely limited by climate [7, $14,46,54]$.

It is commonly accepted that the response of tree-ring growth to climate is constant through time, covering the complete life-span of trees [15]. However, the assumption that the relationship between tree-ring widths and climate is time-stable is questionable, considering the nature of tree ring data and the possibility that climate, and other environmental factors, can change over time $[31,56,59]$. It has also been stated that the history of a tree significantly affects its growth, and tree-ring response to climate can be dependent on age $[8,52]$. Nevertheless, the introduction of the Kalman filter into dendroclimatological analyses has resulted in the development of continuously variable time-dependent relationships between climate and growth [57-59]. Several studies have demonstrated that growth-climate relationships can change over time according to variations in stress factors, such as acidic-deposition or intertree competition [4, 28, 44].

In Europe, pedunculate oak (Quercus robur L.) has proved to be an important species for dendrochronological studies. Archaeological oak timber has been used to successfully date historical buildings [23, 32], and long chronologies, appropriate for use in radiocarbon calibration, have been built from subfossil oak wood preserved in peat bogs and river gravels [1, 39, 40]. Tree-ring responses of pedunculate oak to climate fluctuations have been widely studied in Europe [2, 21, 25, 38, 55]. In northern Spain, studies on oak dendrochronology [17, 18, $34]$, on the climatic response of pedunculate oak [19,44], and climatic reconstructions from oak ring-width chronologies [35] have been performed.

In this work, the relationship between tree growth and climate variables was investigated in Tragamón, an old-growth oak woodland in the Cantabrian lowlands, northern Spain. Time-independent and time-dependent responses of ring-width variation to monthly precipitation and temperature were esti- mated by using correlation analysis, bootstrapped response functions and Kalman filter analysis. Age-specific responses to climatic factors were explored in different oak age-classes. The objectives, relative to the radial-growth patterns of pedunculate oak and their responses to climatic variability, were: (1) to calculate the similarities in radial growth patterns among different tree age-classes, (2) to differentiate the climatic variables that determine tree-ring growth in each age-class, (3) to estimate the temporal shifts in the climatic response of oak, and (4) to assess the individual responses of single trees to climate, according to their agreement with common growth patterns.

\section{MATERIALS AND METHODS}

\subsection{Climatic data}

A complete record of temperature and precipitation, from 1939 to 1998, was obtained from the Gijón meteorological station (Asturias, Spain), $29 \mathrm{~m}$ asl, and approximately $2 \mathrm{~km}$ north-west of the study site. The climate in the area is Atlantic, with temperate and wet winters, and periods of summer drought in occasional years. Rainfall records at the weather station of Gijón showed a minimum from June to August, and a maximum from October to January, with a mean annual precipitation of $977 \mathrm{~mm}$ (Fig. 1). Maximum temperature values occur in July and August, while minimum temperatures are observed from December to February, with a mean annual temperature of $13.9^{\circ} \mathrm{C}$ (Fig. 1). Total annual rainfall and mean annual temperatures, from 1940 to 1998, are shown in Figure 1.

\subsection{Field and laboratory procedures}

All old-growth and mature living oaks, without external evidence of bole decay, and a random sample of young oaks, were cored with increment borers in autumn 2000. Since Tragamón is a protected area, only one core per tree was taken, $100 \mathrm{~cm}$ above ground level, in order to minimise the damage to the trees. Two cores were taken in a few mature trees. Cores were air-dried, glued to wooden mounts and surfaced 
Table I. General statistics characterising chronologies of young, mature and old-growth oaks. The common interval considered for all chronologies was 1905-2000.

\begin{tabular}{lccc}
\hline & Young & Mature & Old-growth \\
\hline Time span & $1905-2000$ & $1775-2000$ & $1664-2000$ \\
Number of trees/cores & $30 / 30$ & $27 / 34$ & $35 / 35$ \\
Number of rings & 1217 & 6023 & 7635 \\
Age range of trees (years) & $24-113$ & $172-225$ & $257-471$ \\
Standard deviation & 0.347 & 0.278 & 0.272 \\
Mean sensitivity & 0.224 & 0.182 & 0.196 \\
First-order autocorrelation & 0.763 & 0.567 & 0.562 \\
Signal-to-noise ratio & 5.13 & 8.55 & 13.57 \\
Expressed population signal & 0.837 & 0.895 & 0.931 \\
Variance in first eigenvector $(\%)$ & 29.9 & 30.7 & 32.9 \\
Mean correlation among trees & 0.221 & 0.292 & 0.279 \\
\hline
\end{tabular}

with progressively finer grades of sandpaper. Tree-ring series were dated following standard procedure [50]. Ring-widths were measured under magnification to the nearest $0.01 \mathrm{~mm}$ with a Velmex UniSlide sliding-stage micrometer interfaced with a computer. The COFECHA computer program [24] was used to test for possible dating or measurement errors against a master site chronology for all trees at the site, regardless of the age class they belonged to. The master chronology was calculated from those ring-width series correctly synchronised and highly inter-correlated. All cores with potential errors were rechecked and corrected if possible. Otherwise, they were omitted from further analyses. Series that had low correlations with the master site chronology (correlation coefficient $R<0.40$ ) were excluded. Elimination of cores, through cross-dating and validation procedures, left a total of 35 old-growth, 27 mature and 30 young trees to be considered for dendroclimatic analysis (Tab. I).

\subsection{Chronology computation}

According to the previously identified oak cohorts in Tragamón [45], the studied trees were grouped into three classes $(<120$ years, 170-225 years, and $>250$ years), based on their age in 2000 (Tab. I). Individual ring-width series were used to construct chronologies for each age class. The ARSTAN computer program [9], designed to eliminate nonclimatic variation, was applied on the ring-width series. Each individual raw ring width series was standardised by using a two-step procedure. The series were first fit to a negative exponential or straight line, and then to a cubic smoothing spline with a $50 \%$ frequency response of 64 years, which was flexible enough to considerably reduce any non-climatic variance [10]. The indices for individual cores were averaged into standard chronologies by applying a biweight robust estimation of the mean value function [11]. Finally, the chronologies were prewhitened by autoregressive modelling. The obtained residual chronologies for each age class were used for all analyses of growth-climate relationships. The statistical quality of the chronologies was assessed by means of the standard basic statistics $[6,9]$. The relationships among age-classes, and through time, were examined using Pearson's correlation between the residual chronologies.

\subsection{Dendroclimatic analysis}

The growth-climate relationships were estimated for the period $1940-1998$, by taking the monthly mean temperatures and total precipitation records as climatic predictors, and the residual index chro- nologies as the dependent variables. An interval of 16 months was selected to define the climatic predictors: from June of the year prior to ring formation $(t-1)$ to September of the year in which the growth ring was formed $(t)$. Correlation coefficients between the residual ringwidth indices, and each of the climatic variables, were calculated in order to derive correlation functions [3]. In response function analyses, the variation of ring-width indices was estimated through multiple regression, after extracting the principal components of the climatic predictors to avoid any inter-correlation between them [15]. Calculations were done using the routine RESBO in the program PRECONK version 5.11 (written by H.C. Fritts, Laboratory of Tree-Ring Research, University of Arizona). This includes a bootstrap method to assess statistical significance of the regression coefficients in response functions [22, 29, 48]. In this work, 1000 iterations were computed to estimate the confidence intervals of regression coefficients $(P<0.05)$. Multiple regression analysis was also carried out by considering, as growth predictors, those climatic variables which showed a significant effect on tree-ring growth, as revealed by correlation and response functions.

The time-dependent climatic response was analysed with the Kalman filter technique [57-59]. This method was used to estimate regression models with time-varying coefficients, which permitted the analysis of the climatic response of radial growth over time [57]. For each residual chronology, a Kalman filter was used to evaluate any temporal variation of growth-climate regression coefficients, especially for those climatic variables which were revealed as significant by the correlation and response functions. The Kalman filter analysis was performed with the KALMAN routine in the program PRECONK. The final output from this analysis included predicted ring-width indices and smoothed values for regression coefficients associated with each climatic variable, with their corresponding $95 \%$ confidence intervals, for each year of the time series. If the confidence interval included zero, the regression coefficient was not considered to be statistically significant at the 0.05 level. If the lines for regression coefficients and confidence intervals were horizontal, it was interpreted that there was no temporal variation in the regression coefficient.

\section{RESULTS}

It was found that the descriptive statistics in all chronologies showed relatively low mean standard deviation and sensitivity. They ranged, respectively, from 0.272 to 0.347 and from 0.182 


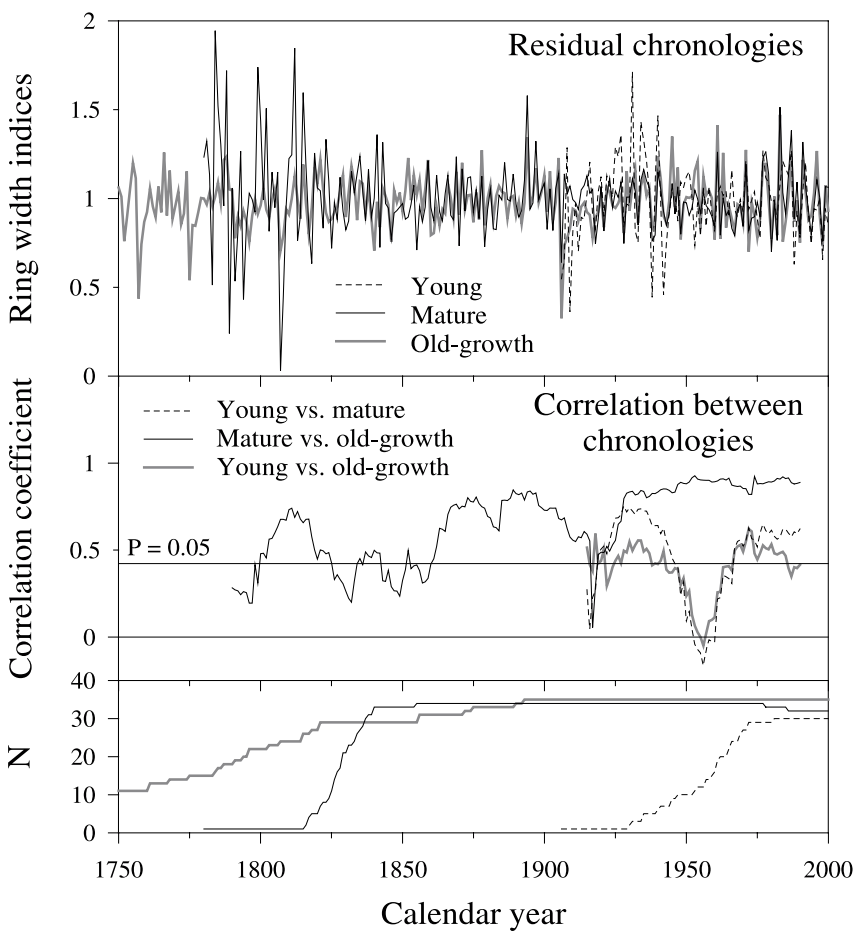

Figure 2. Residual tree-ring chronologies, cross correlation between the residual chronologies, calculated using 20-year segments lagged by one year, and cores sample size $(N)$, for young, mature and oldgrowth oaks in Tragamón. The critical values $(P=0.05)$ for correlation coefficients are shown.

to 0.224 (Tab. I). The first-order autocorrelation was higher for young trees, while the signal-to-noise ratio and the expressed population signal were higher for old-growth trees. The common variance in the first eigenvector was lower for young trees and higher for old-growth trees, and the mean correlation among trees was considerably low in all chronologies, ranging from $R=0.221$ for young trees to $R=0.292$ for mature trees (Tab. I).

Figure 2 portrays the residual oak chronologies and the cross correlations between them. Correlations between the different chronologies greatly varied through time, but more significantly positive correlations were obtained between the chronologies of mature and old-growth oaks than between these and the ones of young oaks (Fig. 2). This was particularly true for the complete period of analysis, 1939-1998, in which higher correlations between residual chronologies from mature and old-growth trees were obtained (young vs. mature $R=0.449$, mature vs. old-growth $R=0.828$, young vs. old-growth $R=$ $0.371, D F=58$ and $P<0.01$ in all tests).

$55.2,60.8$ and $66.8 \%$ of the variance in the residual chronologies of young, mature and old-growth oaks, was explained by bootstrapped response functions calculated for the period 1940-1998 (Fig. 3). It was also found that certain aspects of growth-climate association were independent of tree age, while others differed among the age groups. All age classes shared a common negative correlation with the June and August temperatures of year $t$, and a positive relationship with the June pre-
Table II. Percentage of growth variance explained by monthly climatic variables in young, mature and old-growth oaks, according to multiple regression analyses. Only those climatic variables with a significant $(P<0.05)$ positive $(+)$ or negative $(-)$ relationship to indices of residual chronologies are included. $R^{2}$ values, all of them significant at 0.01 level, are shown.

\begin{tabular}{lccc}
\hline & Young & Mature & Old-growth \\
\hline Temperature & & $13.49(-)$ & $10.04(-)$ \\
$\quad$ January $(t)$ & & & \\
$\quad$ June $(t)$ & $15.10(-)$ & $5.88(-)$ & \\
Precipitation & & & \\
$\quad$ December $(t-1)$ & & $23.28(+)$ & $26.30(+)$ \\
$\quad$ July $(t)$ & 0.151 & 0.426 & 0.451 \\
$R^{2}$
\end{tabular}

cipitation of year $t$ (Fig. 3). Chronologies of both young and mature oaks showed a negative correlation with the May temperatures. By contrast, the negative relationship with temperatures in December and January, and the positive relationship with the July precipitation of year $t$, were common to mature and old-growth oaks (Fig. 3). On the other hand, young-oak chronology had a unique positive correlation with the May precipitation, while old-growth oak chronology showed a positive relationship with the precipitation in December of year $t-1$ and August of year $t$ (Fig. 3). According to response functions, the radial growth of young oaks was mainly controlled by temperatures in June of year $t$, while the January temperatures and the precipitation in June-July of year $t$ were the climatic factors that controlled radial growth in mature oaks (Fig. 3). Moreover, temperatures in January and August of year $t$, and precipitation in July of year $t$, mainly controlled the radial growth in oldgrowth oaks, as revealed by the response function (Fig. 3).

Multiple regression analyses gave shape to the percentage of growth variation explained by climatic variables in the three studied age-classes (Tab. II). These analyses suggested a similar climatic response for mature and old-growth oaks, while young oaks showed their own particular response to climate. The main monthly climatic variables that determined radial growth in mature, as well as old-growth oaks, were the January temperatures, which displayed a negative relationship, and the July precipitation of year $t$, which had a positive effect. On the contrary, the high temperatures in June of year $t$ significantly limited radial growth in young oaks (Tab. II).

The expected growth indices, according to the climatic variability, revealed that the responses of mature and old-growth oaks were closely related, more than with young oaks. As derived from climatic data in the period 1940-1998, a graphical comparison of the predicted growth indices, following the response functions, suggested a great similarity between the reconstructed radial growth for mature and old-growth oaks (Fig. 4). Correlations calculated from the ring width indices, predicted from climate, were higher between mature and old-growth 


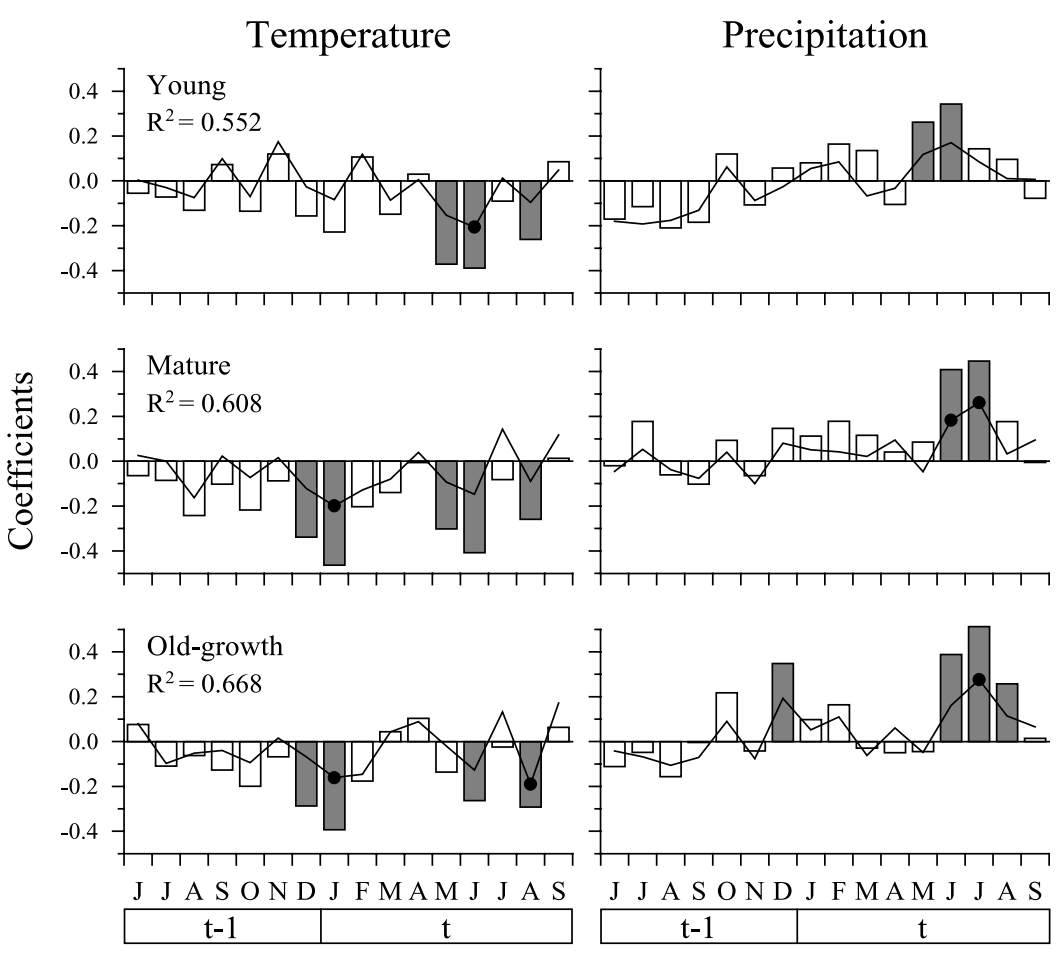

Months

Figure 3. Correlation (bars) and bootstrapped response function coefficients (lines) for young, mature and old-growth oaks in the period 19401998. Shaded bars and solid points indicate significant coefficients at the 0.05 level. $R^{2}$-values indicate the proportion of variance accounted for by the response function model.

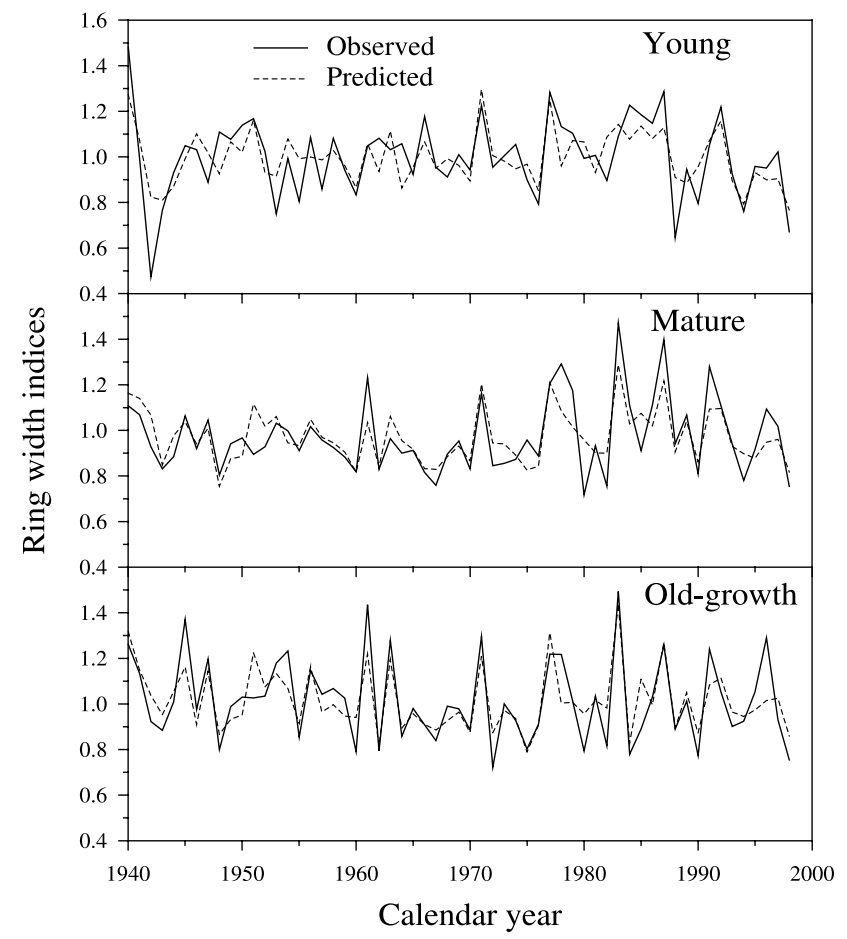

Figure 4. Relationship between the observed ring width indices and the predicted ones according to the bootstrapped response function analysis in the period 1940-1998, for young, mature and old-growth oaks. oaks, even if all the correlation coefficients were statistically significant (young vs. mature $R=0.647$, mature vs. old-growth $R=0.871$, young vs. old-growth $R=0.595, D F=57$ and $P<$ 0.001 in all tests).

Kalman filter analyses indicated that the growth-climate relationship was stable for several climatic variables, but showed a temporal variation in certain cases (Fig. 5). Response functions indicated a constant negative effect of mean temperature in December of year $t-1$ and January of year $t$, on mature and old-growth oaks, no effect on young ones (Fig. 5). By contrast, mean temperature in May-June of year $t$ displayed an increasing negative impact on radial growth of young oaks, a significant negative effect on mature oaks since 1967, and no effect on old-growth oaks. In the case of temperatures in August of year $t$, response functions indicated a constant negative effect on radial growth in all age-classes (Fig. 5). A constant positive influence of precipitation in December of year $t-1$ was displayed on ring-widths of old-growth trees only. Finally, analyses of time-dependent growth-climate relationships for mean precipitation in June-July of year $t$, indicated a positive influence on all oak age-classes during the complete period of analysis (Fig. 5).

The correlation coefficients between the standardised treering series of individual trees and the corresponding residual chronology, according to the age class in which each tree belonged, were calculated. The correlation coefficients between the tree-ring indices of individual trees and the most important climatic variables for tree growth, were also calculated. The 

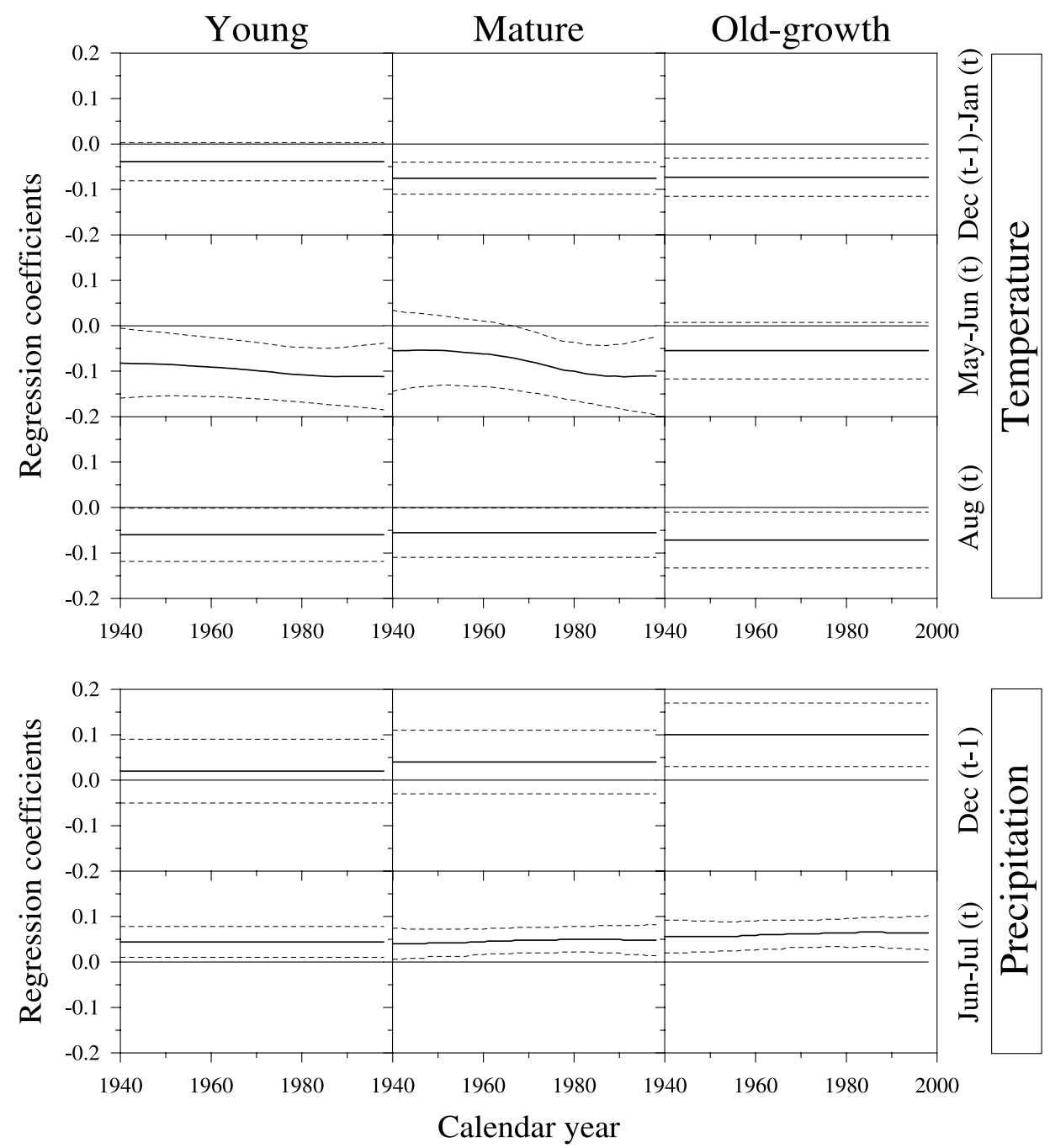

Figure 5. Time-dependent response functions for temperature and precipitation, as determined by Kalman filter analysis, for young, mature and old-growth oaks. Solid lines are the values of the regression coefficients, dashed lines are the $95 \%$ confidence intervals for the regression coefficients.

correlation coefficients for the climatic variables were plotted against the correlation coefficients for the chronology. For illustrative purposes only, the slope of the linear regression, and the significance of the deviation of this slope from zero, were calculated. In the case of temperatures in January and June of year $t$, the slope was significantly negative, indicating an overall inverse climate-growth relationship for these climatic variables (Fig. 6). The slope of the linear trend in the case of the June-July precipitation of year $t$ also significantly differed from zero, indicating a positive climate-growth relationship in the case of this variable. In all cases, correlations with the chronologies and the climate variables did not show up groups of trees belonging to different age classes. However, a best graphical adaptation of mature and old-growth trees to the regression lines, and a greater dispersion among young trees, were evident in all cases (Fig. 6).

\section{DISCUSSION}

\subsection{Comparison of chronologies}

Descriptive statistics indicated that the oak chronologies in Tragamón were comparable to chronologies in other localities in northern Spain and western Europe. Standard deviations can range between $0.20-0.33$, mean sensitivity can reach values between $0.14-0.31$, first-order autocorrelation can vary between $0.30-0.73$, the signal-to-noise ratio usually reaches between $1.8-10.0$, with exceptionally high values of up to 13.2 , and the mean correlation among trees normally ranges between $0.19-0.53$ [18, 34-37]. These statistics are also comparable to those obtained from dendroclimatic studies in other broad-leaved tree species growing in temperate latitudes in both northern and southern hemispheres (e.g. [13, 27, 31, 43, 51, 54]). According 


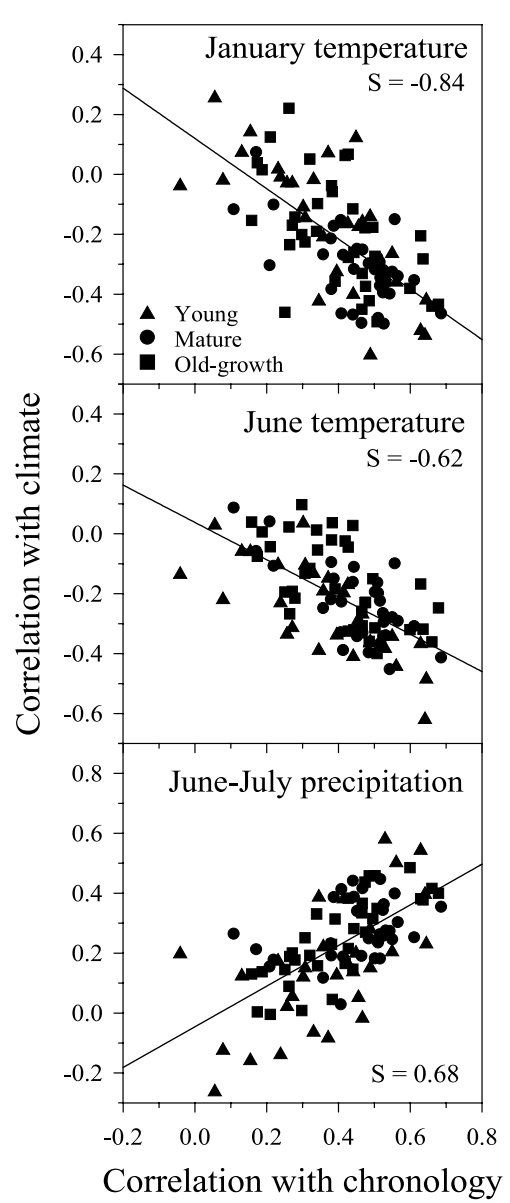

Figure 6. Correlations of the individual ring-width indices with treering index chronologies and climate variables. The lineal trends of scatter plots and their slope values $(\mathrm{S})$ are shown $(N=99$ and $P<0.001$ in all tests).

to these characteristics, the standard deviation and the first-order autocorrelation in the chronology of young oaks are atypically high in Tragamón. This result could be because the previously calculated ranges of variation were derived from chronologies of adult trees only, which probably differed from young trees in their year-to-year sensitivity to local variations in environmental conditions.

Mean sensitivity is a measure of the relative variability in growth indices between adjacent rings, with high values indicating greater variability [15]. First-order autocorrelation is a measure of the correlation between successive values in a time series, and a high autocorrelation indicates that growth for any given year has been strongly influenced by growth in preceding years [15]. In this study, comparative statistics indicated that the chronology of young oaks exhibited the highest sensitivity, but the lowest variance in the first eigenvector and inter-tree correlation. Moreover, the high value of first-order autocorrelation indicated a more persistent lag effect in young oaks than in mature and old-growth trees. The lower values of mean sensitivity in mature and old-growth oaks can be a consequence of growth releases and suppressions in some trees. Abrupt growth changes were greatly reduced after prewhitening in the residual chronologies, but they were not completely removed. However, growth suppressions and releases were infrequent in the period of analysis (1940-1998) [45], and presumably these did not significantly affect the examination of growth-climate relationships. The difference in mean sensitivity and first-order autocorrelation between young and older trees can be also influenced by the ratio between earlywood and latewood, which usually decreases with age [48]. It was found that, in ring-porous species, earlywood width is influenced by growth in the previous growing season $[19,53]$, probably because cambial activity initiation precedes bud burst and leaf expansion. A greater earlywood percentage on total ring-width in young oaks could account for their highest autocorrelation in Tragamón.

Moreover, the signal-to-noise ratio and the expressed population signal are highest in old-growth trees. These statistics measure the degree to which the average ring indices of the chronology reflect the common growth variation in the individual ring-width series, and there is a mathematical relationship between both statistics [6]. The expressed population signal, or agreement with population chronology, usually ranges between 0.77 and 0.92 [13, 53, 54]. The obtained statistics are within, or over, this range, indicating that the obtained tree-ring chronologies are representative of the common growth variation in the population of each age-class. Although the mean correlations between trees are low, these are comparable to the ones previously calculated from other broad-leaved trees growing in dense temperate forests, which can range from 0.13 to 0.61 , and the values between 0.24 and 0.38 are more frequent $[13,27,43,60]$. In general, the average correlation between trees increases when climatic stress increases (e.g. along a precipitation gradient from mesic to xeric conditions [26, 49]). In non-stressful sites, such as under the lowland maritime conditions in Tragamón, average correlation between individual ring-width series are logically lower than in more stressful sites.

\subsection{Time-independent responses to climate}

The percentage of radial growth variation as related to climate in Tragamón, which varied between 55.2 and $66.8 \%$, was within the usual range for oak in other western Europe localities, which can range between 5 and $72 \%$, although percentages greater than $50 \%$ are infrequent $[20,25,38]$. The obtained percentages were also higher in comparison with those calculated from other sites in northern Spain, in which the proportion of growth variation accounted for by climate was from 29 to $52 \%$ $[35,44]$. There are two possible explanations for the different impacts of climate on growth of oaks in these localities. First, Tragamón is a park-like woodland with a low density of trees, consequently inter-tree competition for resources should not have limited growth. By contrast, in the other localities the forests are more or less dense, dominated by oak species ( $Q$. robur, $Q$. petraea (Matt.) Liebl., Q. pyrenaica Willd., and hybrids) [34], and beech (Fagus sylvatica L.) in one case only [44], in which resource-competition should be intense and probably obscured the climatic signal on radial growth. Also, Tragamón is very close to the weather station in Gijón, approximately $2 \mathrm{~km}$, therefore its particular microclimate should not differ significantly from the climatic records. This suggests that the similitude 
between the climatic conditions under which the trees have grown, and the climatic data used to study the response of oak growth, could account for the strong growth-climate relationship obtained in Tragamón.

The results of the time-independent analyses indicated that the radial-growth response of oak trees to climate in Tragamón varied with tree age in some aspects, but not in others. Stand dynamics and the variation of inter-tree competition is a feasible explanation, because the relative canopy position and the competition intensity can result in contrasting radial growth responses to climate $[4,33,41,44]$. However, the canopy position in almost all oak trees sampled in Tragamón was dominant, and any competition between neighbouring trees should not have been relevant in interpreting their climatic responses because of the low tree density and the sparse arrangement of adult oaks.

A more convincing explanation is that contrasting responses may reflect physiological changes related to tree ageing. Changes in hormone balances that govern cambial growth, shifts in the ratio of photosynthetic to non-photosynthetic tissues, and any modification in the mechanisms of absorption and translocation of water and metabolites that occur during ageing, could affect the response of tree-ring growth to climate [54]. Physiological processes dependent on tree age have been suggested as determinants of the stability of tree-ring responses to climate $[8,52,54]$, but this point has never been proved. Further work is required to establish whether age-dependent climatic responses have a physiological basis. However, performing ecophysiological experiments on trees of a wide range of ages, to know the effects of climatic variability on radial growth, is almost impractical. Physiologically based models could be beneficial to estimate the effects of climate on the physiology and radial growth of differently aged oaks $[12,16]$.

While high temperatures in June mainly limited the radial growth of young oaks, high temperatures in January, and low precipitation in July (Fig. 3 and Tab. II) mainly limited growth in mature and old oaks. The negative effect of summer temperatures on oak growth has been previously observed in several localities of Continental Europe [20, 21], in northern Spain [35, $44]$ and also in the Mediterranean region [47, 55]. High summer temperatures may induce increased water stress and a subsequent decrease in radial growth, due to elevated water loss associated with evapotranspiration and soil water evaporation. However, a contrary response of oak growth to summer temperatures has been observed in other localities in Atlantic Europe. In the British Isles, oak often shows a positive response to summer temperatures [25, 38], probably because summer water stress is not as pronounced as in Continental Europe. By contrast, the negative effect of winter temperatures, especially in December and January, has been widely documented throughout Western Europe [5, 20, 21, 25, 38]. This inverse relationship between winter temperatures and growth during a following season may result from the respiratory loss of carbohydrate reserves at high temperatures, when the trees have no leaves to compensate for this loss [38].

Summer precipitation, especially in June and July, greatly benefited the radial growth of oak in Tragamón (Fig. 3). This positive effect of summer rainfall on oak ring-widths is a general feature throughout Europe. In various Atlantic, Mediter- ranean and Central European areas, oak radial growth shows a positive relationship with summer precipitation $[2,5,20,21$, $38,44,47,55]$. Summer rainfall influences the cambial activity, and permits a prolongation of the growing season into late fall, giving larger latewood widths and wider growth-rings [19, 53].

\subsection{Time-dependent responses to climate}

Kalman filter analyses indicated that the response of pedunculate oak ring-widths to specific climatic variables varied through time (Fig. 5). However, gradual changes in growth-climate associations were not observed in other cases. In previous studies of oak dendroclimatology in western Europe, a certain stability of climatic response across different periods has been noted [21, 44]. However, investigations in other oak species revealed that tree growth-climate relationships can vary through time as a result of an interaction with changes in environmental stress factors, such as air pollution [28, 31]. Some possible explanations for the temporal variation in the climatic response of pedunculate oak in Tragamón included a natural change associated with stand maturation or tree ageing, and a shift induced by temporal variation in other environmental conditions. The variation in the response of oaks to climate in Tragamón can not be attributed to environmental changes, such as reductions in the canopy closure due to disturbances. Such interactions with canopy disturbances usually enhance the climatic response when competition intensity was reduced [41, 44]. The climatic signal contained in the chronologies may be temporally offset by new limiting factors, such as high competition intensity [54].

However, the changes observed in the growth-climate association in Tragamón appear to be gradual, as could be expected if they were due to ageing. Tree maturation itself could be a suitable hypothesis to explain the gradual shift in the response of oaks to temperatures in May-June, and to precipitation in JuneJuly of year $t$ (Fig. 5), because the maturation process was constant across all the sampled trees. The response of oaks to December precipitation in year $t-1$ was constant through time, but regression coefficients become larger with age, being significant in old-growth oaks (Fig. 5). This result could be indicative of a negative relationship with soil water depletion in the early growing season, which could reduce leaf development and photosynthate production in this age class. A common feature in old-growth trees is crown die back, with a reduction of productivity due to damage and decay [30, 42]. The limited capacity to produce photosynthetic material suggest that old trees may become more sensitive to insufficient water supply than young or mature trees, due to a loss of the ability to increase their absorptive root area. Nevertheless, this work demonstrated that the climatic response of pedunculate oak can vary through time, and that such variations could be dependent on tree age. However, the ecophysiological cause-effect relationships between tree ageing and the climatic responses are not yet completely understood.

\section{CONCLUSION}

Dendroecological investigations commonly focus on the use of correlation and response functions for modelling the climatic 
information contained in a tree ring series. In this study, the coupled analyses of time-independent and time-dependent responses of tree-ring growth to climate, revealed age-specific climate-growth relationships in pedunculate oak, which could also reflect physiological changes related to ageing. Mature and old-growth oaks showed a climatic response that was typical for this species in Continental Western Europe, with a negative relationship to winter (January) temperatures, and a positive one to summer (July) precipitation. However, high temperatures in June of the year in which the tree-ring was formed mainly limited radial growth of young oaks. Moreover, the positive response of old-growth oaks to precipitation in winter (December), could result from a loss of the ability to increase their absorptive root area due to damage and decay, which enhanced the effects of soil water deficiency early in the growing season. The results presented here also demonstrate that a temporal shift can be found in the climatic responses of pedunculate oak. The approach used in this examination of long-term weather responses of coexisting, discrete oak age-classes would appear to be an important first step in understanding and anticipating the responses of old-growth pollarded woodlands to future climatic changes in Europe.

Acknowledgements: The author thanks Juan Luis Menéndez and Francisco Javier Suárez for field assistance, and Kenneth McKenney for correcting the English manuscript. The comments and suggestions of two anonymous reviewers greatly improved the quality of the paper. The Ayuntamiento de Gijón and the Dirección General de Recursos Naturales y Protección Ambiental del Principado de Asturias gave permission for taking the cores. This research was supported by the Consejería de Medio Ambiente del Principado de Asturias (SV-PA-00-01).

\section{REFERENCES}

[1] Becker B., An 11 000-year German oak and pine dendrochronology for radiocarbon calibration, Radiocarbon 35 (1993) 201-213.

[2] Bednarz Z., Ptak J., The influence of temperature and precipitation on ring widths of oak (Quercus robur L.) in the Niepolomice forest near Cracow, Southern Poland, Tree-Ring, Bull. 50 (1990) 1-10.

[3] Blasing T.J., Solomon A.M., Duvick D.N., Response functions revisited, Tree-Ring Bull. 44 (1984) 1-15.

[4] Brakel J.A., van den Visser H., The influence of environmental conditions on tree-ring series of Norway spruce for different canopy and vitality classes, For. Sci. 42 (1996) 206-219.

[5] Bridge M.C., Gasson P.E., Cutler D.F., Dendroclimatological observations on trees at Kew and Wakehurst Place: event and pointer years, Forestry 69 (1996) 263-269.

[6] Briffa K., Jones P.D., Basic chronology statistics and assessment, in: Cook E., Kairiukstis L. (Eds.), Methods of dendrochronology: applications in the environmental sciences, Kluwer Academic Publishers, Dordrecht, 1990, pp. 137-152.

[7] Cleaveland M.K., Duvick D.N., Iowa climate reconstructed from tree rings, 1640-1982, Water Resour. Res. 28 (1992) 2607-2615.

[8] Colenutt M.E., Luckman B.H., Dendrochronological investigation of Larix lyallii at Larch Valley, Alberta, Can. J. For. Res. 21 (1991) 1222-1233.

[9] Cook E.R., Holmes R.L., Guide for computer program ARSTAN, in: Grissino-Mayer H.D., Holmes R.L., Fritts H.C. (Eds.), The International Tree-Ring Data Bank Program Library Version 2.0 User's Manual, Laboratory of Tree-Ring Research, University of Arizona, Tucson, 1996, pp. 75-87.
[10] Cook E.R., Peters K., The smoothing spline: a new approach to standardizing forest interior tree-ring width series for dendroclimatic studies, Tree-Ring Bull. 41 (1981) 45-53.

[11] Cook E., Briffa K., Shiyatov S., Mazepa V., Tree-ring standardization and growth-trend estimation, in: Cook E., Kairiukstis L. (Eds.), Methods of dendrochronology: applications in the environmental sciences, Kluwer Academic Publishers, Dordrecht, 1990, pp. 104132.

[12] Cook E.R., Johnson A.H., Blasing T.J., Forest decline: modeling the effect of climate in tree rings, Tree Physiol. 3 (1987) 27-40.

[13] Cullen L.E., Palmer J.G., Duncan R.P., Stewart G.H., Climate change and tree-ring relationships of Nothofagus menziesii tree-line forests, Can. J. For. Res. 31 (2001) 1981-1991.

[14] Dittmar C., Zech W., Elling W., Growth variation of common beech (Fagus sylvatica L.) under different climatic and environmental conditions in Europe - a dendroecological study, For. Ecol. Manage. 173 (2003) 63-78.

[15] Fritts H., Tree rings and climate, Academic Press, London, 1976.

[16] Foster J.R., LeBlanc D.C., A physiological approach to dendroclimatic modeling of oak radial growth in the midwestern United States, Can J. For. Res. 23 (1993) 783-798.

[17] García González I., Díaz Vizcaíno E.A., Martínez Cortizas A., Evidence for a common and a species-specific climatic response of oak and birch on a northern Galician site (NW Spain) by means of multivariate procedures, Dendrochronologia 15 (1997) 119-127.

[18] García González I., Díaz Vizcaíno E.A., Martínez Cortizas A., Dendrochronological analysis of oak (Quercus robur L., Fagaceae) in the Serra da Carba (Galicia, NW Spain): an application of cluster analysis, Nova Acta Científica Compostelana (Bioloxía) 9 (1999) 171-177.

[19] García González I., Eckstein D., Climatic signal of earlywood vessels of oak on a maritime site, Tree Physiol. 23 (2003) 497-504.

[20] Gray B.M., Pilcher J.R., Testing the significance of summary response functions, Tree-Ring Bull. 43 (1983) 31-38.

[21] Gray B.M., Wigley T.M.L., Pilcher J.R., Statistical significance and reproducibility of tree-ring response functions, Tree-Ring Bull. 41 (1981) 21-35.

[22] Guiot J., Methods of calibration, in: Cook E., Kairiukstis L. (Eds.), Methods of dendrochronology: applications in the environmental sciences, Kluwer Academic Publishers, Dordrecht, 1990, pp. 165178.

[23] Hillam J., The dating of archaeological sites in the United Kingdom, Lundqua Rep. 34 (1992) 146-149.

[24] Holmes R.L., Computer-assisted quality control in tree-ring dating and measurement, Tree-Ring Bull. 43 (1983) 69-78.

[25] Hughes M.K., Gray B., Pilcher J., Baillie M., Leggett P., Climatic signals in British Isles tree-ring chronologies, Nature 272 (1978) 605-606.

[26] Jacobi J.C., Tainter F.H., Dendroclimatic examination of white oak along an environmental gradient in the Piedmont of South Carolina, Castanea 53 (1988) 252-262.

[27] Lara A., Aravena J.C., Villalba R., Wolodarsky-Franke A., Luckman B., Wilson R., Dendroclimatology of high-elevation Nothofagus pumilio forests at their northern distribution limit in the central Andes of Chile, Can. J. For. Res. 31 (2001) 925-936.

[28] LeBlanc D.C., Temporal and spatial variation of oak growth-climate relationships along a pollution gradient in the midwestern United States, Can. J. For. Res. 23 (1993) 772-782.

[29] Lebourgeois F., Climatic signals in earlywood, latewood and total ring width of Corsican pine from western France, Ann. For. Sci. 57 (2000) 155-164. 
[30] Lonsdale D., Pollarding success or failure: some principles to consider, in: Read H.J. (Ed.), Pollard and Veteran Tree Management, II, Corporation of London, Burnham Beeches, 1996, pp. 100-104.

[31] McClenahen J.R., Dochinger L.S., Tree ring response of white oak to climate and air pollution near the Ohio River Valley, J. Environ. Qual. 14 (1985) 274-280.

[32] Morgan R.A., Litton C.D., Salisbury C.R., Trackways and tree trunks - dating Neolithic oaks in the British Isles, Tree-Ring Bull. 47 (1987) 61-69.

[33] Orwig D.A., Abrams M.D., Variation in radial growth responses to drought among species, site, and canopy strata, Trees 11 (1997) 474-484.

[34] Pérez Antelo A., Fernández Cancio A., Dendrocronologias de las sierras orientales gallegas: Los Ancares y El Courel (España), Invest. Agrar. Sist. Recur. For. 4 (1995) 5-31.

[35] Pérez Antelo A., Fernández Cancio A., Reconstrucciones dendroclimatológicas de Galicia (España) desde finales del siglo XVIII, Invest. Agrar. Sist. Recur. For. 6 (1997) 17-37.

[36] Pilcher J.R., Baillie M.G., Six modern oak chronologies from Ireland, Tree-Ring Bull. 40 (1980) 23-34.

[37] Pilcher J.R., Baillie M.G., Eight modern oak chronologies from England and Scotland, Tree-Ring Bull. 40 (1980) 45-58.

[38] Pilcher J.R., Gray B., The relationships between oak tree growth and climate in Britain, J. Ecol. 70 (1982) 297-304.

[39] Pilcher J.R., Baillie M.G.L., Schmidt B., Becker B., A 7,272 year tree-ring chronology for western Europe, Nature 312 (1984) 150152 .

[40] Pilcher J.R., Hillam J., Baillie M.G.L., Pearson G.W., A long subfossil oak tree-ring chronology from the north of Ireland, New Phytol. 79 (1977) 713-729.

[41] Piutti E., Cescatti A., A quantitative analysis of the interactions between climatic response and intraspecific competition in European beech, Can. J. For. Res. 27 (1997) 277-284.

[42] Read H., Veteran trees: a guide to good management, English Nature, The Countryside Agency and English Heritage, Peterborough, 2000.

[43] Robertson P.A., Factors affecting tree growth on three lowland sites in southern Illinois, Am. Midl. Nat. 128 (1992) 218-236.

[44] Rozas V., Detecting the impact of climate and disturbances on treerings of Fagus sylvatica L. and Quercus robur L. in a lowland forest in Cantabria, Northern Spain, Ann. For. Sci. 58 (2001) 237251

[45] Rozas V., Dendrochronology of pedunculate oak (Quercus robur L.) in an old-growth pollarded woodland in northern Spain: establishment patterns and the management history, Ann. For. Sci. 62 (2005) 13-22.
[46] Rubino D.L., McCarthy B.C., Dendroclimatological analysis of white oak (Quercus alba L., Fagaceae) from an old-growth forest of southeastern Ohio, USA, J. Torrey Bot. Soc. 127 (2000) 240250

[47] Santini A., Bottacci A., Gellini R., Preliminary dendroecological survey on pedunculate oak (Quercus robur L.) stands in Tuscany (Italy), Ann. Sci. For. 51 (1994) 1-10.

[48] Splechtna B.E., Dobry J., Klinka K., Tree-ring characteristics of subalpine fir (Abies lasiocarpa (Hook.) Nutt.) in relation to elevation and climatic fluctuations, Ann. For. Sci. 57 (2000) 89-100.

[49] Stahle D.W., Hehr J.G., Dendroclimatic relationships of post oak across a precipitation gradient in the southcentral United States, Ann. Assoc. Amer. Geogr. 74 (1984) 561-573.

[50] Stokes M.A., Smiley T.L., An introduction to tree-ring dating, University of Chicago Press, Chicago, 1968.

[51] Szeicz J.M., Growth trends and climatic sensitivity of trees in the North Patagonian rain forest of Chile, Can. J. For. Res. 27 (1997) 1003-1014.

[52] Szeicz J.M., MacDonald G.M., Age-dependent tree-ring growth responses of subarctic white spruce to climate, Can. J. For. Res. 24 (1994) 120-132.

[53] Tardif J., Earlywood, latewood and total ring width of a ring-porous species (Fraxinus nigra Marsh.) in relation to climatic and hydrological factors, in: Dean J.S., Meko D.M., Swetnam T.W. (Eds.), Tree rings, environment and humanity, radiocarbon, 1996, pp. 315324.

[54] Tardif J., Brisson J., Bergeron Y., Dendroclimatic analysis of Acer saccharum, Fagus grandifolia, and Tsuga canadensis from an oldgrowth forest, southwestern Quebec, Can. J. For. Res. 31 (2001) 1491-1501.

[55] Tessier L., Nola P., Serre-Bachet F., Deciduous Quercus in the Mediterranean region: tree-ring/climate relationships, New Phytol. 126 (1994) 355-367.

[56] Van Deusen P.C., Evaluating time-dependent tree ring and climate relationships, J. Environ. Qual. 19 (1990) 481-488.

[57] Visser H., Analysis of tree ring data using the Kalman filter technique, IAWA Bull. 7 (1986) 29-37.

[58] Visser H., Molenaar J., Kalman filter analysis in dendroclimatology, Biometrics 44 (1988) 929-940.

[59] Visser H., Molenaar J., Detecting time-dependent climatic response in tree rings using the Kalman filter, in: Cook E., Kairiukstis L. (Eds.), Methods of dendrochronology: applications in the environmental sciences, Kluwer Academic Publishers, Dordrecht, 1990, pp. 270-277.

[60] Yasue K., Funada R., Kondo T., Kobayashi O., Fukazawa K., The effect of climatic factors on the radial growth of Japanese ash in northern Hokkaido, Japan, Can. J. For. Res. 29 (1996) 2052-2055. 